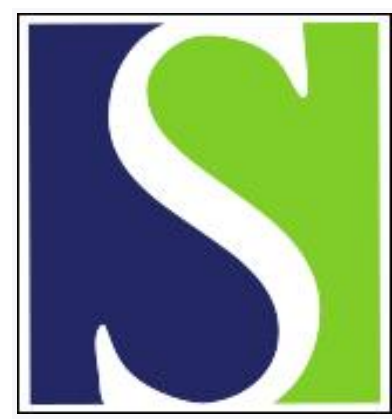

Scand J Work Environ Health 2008;34(6):471-478

https://doi.org/10.5271/sjweh.1292

Issue date: 00 Dec 2008

Sharpening the focus on occupational safety and health in nanotechnology

by Schulte P, Geraci C, Zumwalde R, Hoover M, Castranova V, Kuempel E, Murashov V, Vainio H, Savolainen K

Affiliation: National Institute for Occupational Safety and Health, Centers for Disease Control and Prevention, 4676 Columbia Parkway, MS C-14, Cincinnati, OH 45226, USA. PSchulte@cdc.gov

The following article refers to this text: 2008;34(6):407-409

Key terms: discussion paper; engineering; exposure; hazard; nanoparticle; nanotechnology; occupational health; occupational safety; occupational safety and health; risk

This article in PubMed: www.ncbi.nlm.nih.gov/pubmed/19137209 


\title{
Sharpening the focus on occupational safety and health in nanotechnology
}

\author{
by Paul Schulte, PhD, ${ }^{1}$ Charles Geraci, PhD, ${ }^{1}$ Ralph Zumwalde, MS, ${ }^{1}$ Mark Hoover, PhD, ${ }^{1}$ Vincent \\ Castranova, PhD, ${ }^{1}$ Eileen Kuempel, PhD, ${ }^{1}$ Vladimir Murashov, PhD, ${ }^{1}$ Harri Vainio, MD, ${ }^{2}$ \\ Kai Savolainen, $M D^{2}$
}

\begin{abstract}
Schulte P, Geraci C, Zumwalde R, Hoover M, Castranova V, Kuempel E, Murashov V, Vainio H, Savolainen K. Sharpening the focus on occupational safety and health in nanotechnology. Scand $J$ Work Environ Health 2008;34(6):471-478.

Increasing numbers of workers are involved with the production, use, distribution, and disposal of nanomaterials At the same time, there is a growing number of reports of adverse biological effects of engineered nanoparticles in test systems. It is useful, at this juncture, to identify critical questions that will help address knowledge gaps concerning the potential occupational hazards of these materials. The questions address (i) hazard classification of engineered nanoparticles, (ii) exposure metrics, (iii) the actual exposures to the different engineered nanoparticles in the workplace, (iv) the limits of engineering controls and personal protective equipment with respect to engineered nanoparticles, (v) the kinds of surveillance programs that may be required at workplaces to protect potentially exposed workers, (vi) whether exposure registers should be established for workers potentially exposed to engineered nanoparticles, and, (vii) whether engineered nanoparticles should be treated as "new" substances and evaluated for safety and hazards?
\end{abstract}

Key terms engineering; exposure; hazard; nanoparticle; risk.

It has been almost 50 years since the vision of what nanotechnology could be was first described (1). However, it has only been within the last 15 years that the products of technology have emerged in commerce and within the last 10 years that the first reports of adverse biological effects from in vitro or in vivo studies have been published (2-10). This time difference has created a knowledge gap between the stage of technological progress and our knowledge of the potential hazards of the applications of this new technology. The knowledge gap tends to remain, and even to grow, and it is increasingly difficult to fill, unless new and innovative approaches emerge with which to explore more effectively the safety of nanotechnology innovations. Fortunately, research on ambient or natural ultrafine particles in the last 20 years has laid a rich foundation and, taken together with the recent publications on engineered nanoparticles, has served as the basis for developing interim recommendations for precautionary measures to control engineered nanoparticles in the workplace to protect workers who might be exposed to them (11-17). During the last 5 years, most occupational safety and health organiza- tions have developed reports to raise awareness about the possible hazards of nanotechnology in the workplace $(16,18-23)$. This history can be seen as the first phase in studying the health effects and developing guidance for workers. It is now time to take stock of where we are and focus on what critical questions need to be addressed. This paper identifies the following seven critical questions, the answers to which are needed to move forward our understanding of the hazards of engineered nanoparticles and to enable science-based guidance and risk management to be developed: (i) "Can an algorithm be developed to classify engineered nanoparticles by the degree of potential hazards?", (ii) "Which characteristics of particles and which measurement techniques should be used for the assessment of exposure to engineered nanoparticles?", (iii) "What is the exposure to engineered nanoparticles in the workplace?", (iv) "What are the limits of engineering controls and personal protective equipment with regard to engineered nanoparticles?", (v) "What occupational health surveillance should be recommended for workers potentially exposed to engineered nanoparticles?", (vi) "Should exposure registers

1 National Institute for Occupational Safety and Health, Centers for Disease Control and Prevention, Cincinnati, Ohio, United States.

2 Finnish Institute of Occupational Health, Helsinki, Finland.

Reprint requests to: Dr P Schulte, National Institute for Occupational Safety and Health, Centers for Disease Control and Prevention, 4676 Columbia Parkway, MS C-14, Cincinnati, OH 45226, USA. [E-mail: PSchulte@cdc.gov] 
be established for various groups of workers potentially exposed to engineered nanoparticles?", and (vii) "Should engineered nanoparticles be treated as 'new' substances and evaluated for safety and hazards?"

\section{Can an algorithm be developed for classifying nanopar- ticles by the degree of potential hazard?}

There is a growing and coalescing level of evidence that exposure to some of the engineered nanoparticles can cause adverse effects on health (table 1). This evidence comes from various sources, for example, animal and human studies of ultrafine aerosols, air pollution, and the epidemiology of manmade and mineral fibers, as well as from a great number of in vitro studies with natural and engineered nanoparticles providing mechanistic information on the health effects of both incidental (usually combustion-derived) and various types of engineered nanoparticles $(3,13,15,18,23)$. This evidence has been reviewed by numerous organizations that have concluded that there is enough preliminary information to treat engineered nanoparticles "as if" they are hazardous $(16,19-21,31,32)$. The question is what data and methods are required to support a more definitive and comprehensive hazard identification.

The evidence base that currently exists is relatively sparse and reflects the heterogeneity of engineered nanoparticles. Clearly, there are many inherent parameters that influence the potential toxicity of engineered nanoparticles. They include size, surface area, shape, solubility, surface reactivity, charge, attached functional groups, crystalline structure, the agglomeration status of the particles, and their contaminants. Depending on the combination of these factors, toxicity can be more or less marked, especially in relation to often chemically identical but coarser particles as in the case of titanium dioxide or as found with carbon nanotubes $(4,33,34)$. Potentially confounding differences in how nanoparticles are dispersed and administered for toxicological study may also be reflected in the variability of results concerning nanoparticle toxicity in investigations of "the same" nanoparticles in laboratory animal and in vitro models (10). Moreover, there is a multiplicity of organs that can be targets of nanoparticle exposure (7). At issue are how these factors contribute to the relative hazard or safety of engineered nanoparticles and whether an algorithm can be described to predict hazard classes of nanoparticles. Ultimately, since the universe of potential engineered nanoparticles is huge, it will not be possible to test each particle. Consequently, there is a need to develop and validate strategies for hazard identification that will combine targeted testing with a decision algorithm on hazard projection that will allow particle types (combination of parameters) to be categorized by potential toxicity. This work may involve using new approaches, such as structure activity relationships, or various end points of in vitro tests, such as inflammatory markers or the formation of reactive oxygen species as surrogate indicators of toxicity $(35,36)$. On the basis of this hazard identification, subsequent decisions can be made regarding the assessment, communication, and management of risk. Without it, society is left with a nanoparticle-by-nanoparticle hazard research effort that would exceed all of the currently available resources. Indeed, occupational safety and health experience has shown that a chemical-by-chemical paradigm has been

Table 1. Biological effects of the various engineered nanoparticles. $\left(\mathrm{TiO}_{2}=\right.$ titanium dioxide $)$

\begin{tabular}{|c|c|c|}
\hline Reference & Effect & Particle \\
\hline $\begin{array}{l}\text { Shvedova et al, } 2005 \text { (8); Elder et al, } 2006 \text { (9); } \\
\text { Mercer et al, } 2008 \text { (10) }\end{array}$ & Deposit in the alveoli & $\begin{array}{l}\text { Single-walled carbon nanotubes; ultrafine } \mathrm{TiO}_{2} \text {; } \\
\text { ultrafine carbon black }\end{array}$ \\
\hline Mercer et al, 2008 (10); Renwick et al, 2004 (42) & Evade phagocytosis & $\begin{array}{l}\text { Single-walled carbon nanotubes; ultrafine carbon } \\
\text { black; ultrafine } \mathrm{TiO}_{2}\end{array}$ \\
\hline Mercer et al, 2008 (10); Oberdörster et al, 1994 (37) & Enter alveolar walls & Single-walled carbon nanotubes; ultrafine $\mathrm{TiO}_{2}$ \\
\hline Nikula et al, 1995 (24) & Produce interstitial inflammation & Ultrafine carbon black \\
\hline $\begin{array}{l}\text { Bermudez et al, } 2004 \text { (4); Shvedova et al, } 2005 \text { (8); } \\
\text { Mercer et al, } 2008 \text { (10) }\end{array}$ & Produce fibrosis & Ultrafine $\mathrm{TiO}_{2}$; single-walled carbon nanotubes \\
\hline Nikula et al, 1995 (24); Heinrich et al, 1995 (25) & Produce tumors & Ultrafine $\mathrm{TiO}_{2}$; ultrafine carbon black \\
\hline Shvedova et al, 2005 (8) & Induce granulomas & Single-walled carbon nanotubes \\
\hline Oberdörster et al, 2002 (3) & Enter circulatory system & Ultrafine carbon \\
\hline Li et al, 2007 (26) & Induce plaques on vessel walls & Single-walled carbon nanotubes \\
\hline $\begin{array}{l}\text { Takenaka et al, } 2001 \text { (2); Oberdörster et al, } 2002 \text { (3); } \\
\text { Geiser et al, } 2005 \text { (6) }\end{array}$ & Enter and move through circulatory system & Ultrafine $\mathrm{TiO}_{2}$; silver, and elemental carbon $\left({ }^{13} \mathrm{C}\right)$ \\
\hline $\begin{array}{l}\text { Takenaka et al, } 2001 \text { (2); Oberdörster et al, } 2002 \text { (3); } \\
\text { Geiser et al, } 2005 \text { (6) }\end{array}$ & Enter various organs & Ultrafine $\mathrm{TiO}_{2} ;$ silver, and elemental carbon $\left({ }^{13} \mathrm{C}\right)$ \\
\hline Porter et al, 2007 (27); Porter et al, 2007 (28) & Enter cell nuclei & Single-walled carbon nanotubes; fullerenes $\left(\mathrm{C}_{60}\right)$ \\
\hline Elder et al, 2006 (9); Oberdörster et al, 2004 (29) & Move from nose to brain & $\begin{array}{l}\text { Ultrafine elemental carbon }\left({ }^{13} \mathrm{C}\right) \text {; ultrafine } \\
\text { manganese oxide }\end{array}$ \\
\hline Ryman-Rasmussen et al 2006 (30) & Penetrate epidermis & Quantum dots \\
\hline
\end{tabular}


of limited effectiveness in keeping pace with the needs to develop and update occupational standards for existing chemical substances and physical agents.

\section{Which characteristics of particles and which measure- ment techniques should be used for the assessment of exposure to engineered nanoparticles?}

It appears from animal studies of ultrafine and fine particles that the dose-response relationships for adverse lung responses depends on particle size when the dose of poorly soluble particles is expressed as particle mass, but a range of particle sizes can be fit with the same dose-response relationship when dose is expressed as particle surface area (37-41). Some of the end points for which this phenomenon has been demonstrated are pulmonary inflammation, lung granuloma formation, and lung cancer. It is likely that engineered nanoparticles will follow the same pattern $(8,34,42)$. For example, engineered nanoparticles of titanium dioxide have been observed to show these effects and to have a consistent exposure-response relationship with fine-sized titanium dioxide when plotted on a surface area basis (41). For the estimation of particle surface area, it may be helpful to assess the aerosol size distribution, number and mass concentration, and aerosol charge (which could affect instrumentation and agglomeration) (14). Surface area has not been routinely or historically measured in the workplace, and there is a need for appropriate practical equipment, measurement protocols, and baseline measurements. Several such devices for the measurement of airborne particle surface area are currently under development. The European Commission is strongly supporting the development of such devices within the frame of the 7th Framework Programme on Research (16). Until specific measurement methods for workplace nanoparticle exposure are developed, current recommendations are to obtain airborne concentration measurements as particle mass concentration, number concentration, size distribution or surface area or all using available sampling technology (43). There is a need to develop lower-cost, effective on-line measurement devices for workplace measurement and the identification of engineered airborne nanoparticles (44). The development of new-generation sampling devices using biological metrics of harmfulness (eg, surface reactivity) may also be feasible in the future.

\section{What is the exposure to engineered nanoparticles in the workplace?}

In order to address this question, there is a need to reflect on the fact that there is a diversity of workplaces, from laboratories through manufacturing and production operations, to disposal and recycling (figure 1). Exposures to engineered nanoparticles are likely to vary across workplaces, as well as within a given workplace by job or task. Very little has been published on the number and nature of the workplaces in which engineered nanoparticles are handled (44-46). Even less is known about exposure levels by area, worker, or task. There is a major need for extensive exposure assessment and characterization efforts because the literature on the levels of exposure to engineered nanoparticles is extremely limited. The existing few measurement efforts have identified a substantial number of nondetectable findings and some with relatively low mass concentrations (compared with what has been found with bulk counterparts) (Berges \& Mark, personal communication, 2007) (46). It is not known to what extent these findings, based on limited sampling, are representative of exposures or processes currently occurring in the various workplaces in which nanoparticles are produced or used or how exposures may change as the application of the technology grows. Exposure assessment can build on the vast experience available regarding exposure determination for classical aerosols (47). The following two overarching issues are related to exposure assessment: (i) the need for standardized approaches and (ii) the dissemination of

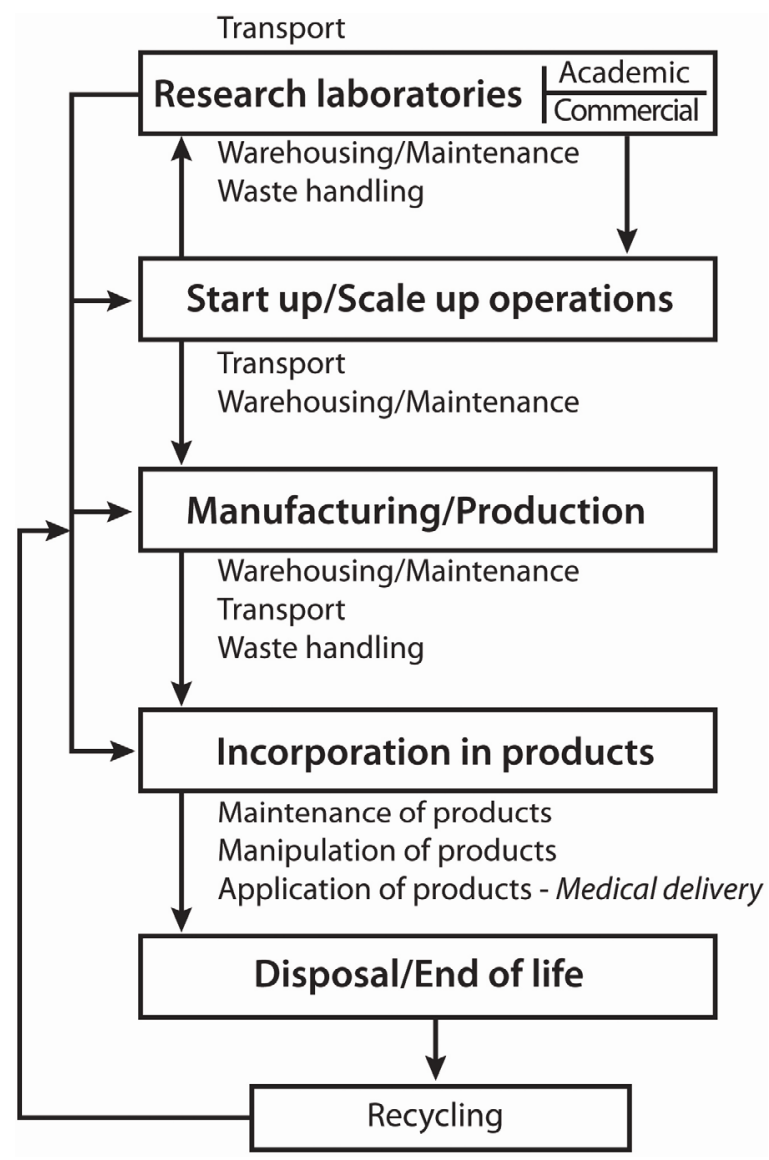

Figure 1. Range of workplaces that could involve exposure to engineered nanoparticles [adapted from the paper by Schulte et al (47)]. 
exposure information possibly in an exposure database. Various efforts are underway to describe standardized approaches (19, 47; see also http:/www.uku.fi/laitokset/ ifk/projects.shtml). More broadly, the Organization for Economic Cooperation and Development is addressing exposure assessment issues (48). The dissemination of measured exposure data will certainly occur in the scientific literature, but there may be value for the next few years in establishing an adhoc exposure database to promote faster dissemination and focus attention on methods being used and issues arising from their use.

Important in exposure assessment is particle characterization, control for incidental (eg, from combustion processes) ultrafine particles, and attention to factors that could influence agglomeration. In addition, the ability for background distinction between the naturally and incidentally occurring and targeted engineered nanoparticles is one of the current key challenges in the assessment of workplace exposures. This work requires devices that could operate at a very wide range of exposure levels and could provide information on particle numbers, particle surface area, particle size distribution, and the chemical composition of nanoparticles to be monitored. Devices with such properties are not currently available, but are under development. Exposure assessment is also necessary for the planning of epidemiologic research and for risk characterization and management. Due to the lack of exposure information on engineered nanoparticles, progress on these efforts has been restricted.

\section{What are the limits of engineering controls and per- sonal protective equipment with regard to engineered nanoparticles?}

The preliminary inference that engineered nanoparticles will follow the classical laws of aerosol physics, fluid dynamics, and filtration theory has been substantiated by field observation and laboratory assessments (19, 47). Therefore, it is reasonable to anticipate that a well-designed ventilation system with a high-efficiency particulate air (HEPA) filter would remove nanoparticles as effectively as it does fine particles $(19,47,49)$. The issues are whether there are limits of these controls when particle size and other parameters inherent in environmental conditions are taken into consideration. There is a need for research on what factors and parameters influence the effectiveness of engineering controls and personal protective equipment with regard to engineered nanoparticles. The leakage of particles around filter media (eg, face seal of respirators), which can occur with airborne particles of any size, is also an area in which additional research is needed for nanoparticles. It should be noted that, if some engineered nanoparticles are more toxic than their larger counterparts, then the risk at exposure levels appropriate for fine particles may be greater for engineered nanoparticles. This risk has not been assessed to date.

The most widely supported approach to preventing exposure from engineered nanoparticles is to follow the hierarchy of controls $(32,47)$. Generally, a control process utilizes some benchmark exposure levels as targets. These levels are generally lacking for engineered nanoparticles. [See the discussion present under the last question.] Thus it has been recommended that exposure be controlled as low as reasonably practical (32). However, there is a need for conducting hazard evaluations and quantitative risk assessments using exposure-response data and then determining what control methods are effective at targeted risk levels. This whole body of work is only in its incipient stages.

\section{What occupational health surveillance should be recommended for workers potentially exposed to engineered nanoparticles?}

Occupational health surveillance should be included as part of a comprehensive and effective occupational safety and health program (50-53). Occupational health surveillance consists of hazard surveillance and medical surveillance and can occur at the workplace or population level. Hazard surveillance is the assessment of the presence of potential hazards in the workplace and the likelihood of exposure (52). Hazard surveillance is a prerequisite for developing a risk management program. Hazard surveillance would involve collecting information on what nanomaterials are being manufactured or handled and where in the workplace exposure might occur. This determination is mostly a matter of management judgment supplemented by environmental measurements and worker input $(52,53)$.

Medical surveillance involves various medical assessments and histories that can be used in preemployment or periodic assessments, or for assessments related to specific functions, such as the wearing of a respirator or in response to untoward events like spills or explosions. Medical screening is a form of medical surveillance; it involves administering a medical test to an asymptomatic person to identify a potential health condition that can be treated in a timely fashion. Occupational health surveillance is also a means of assessing whether the application of steps in the hierarchy of prevention have been successful in controlling exposures and preventing disease. Currently, it is not clear that, beyond hazard surveillance and routine medical surveillance, there is any specific medical testing that is warranted for workers potentially exposed to engineered nanoparticles (53). This situation arises due to the scarcity of research that has been conducted linking exposure to engineered nanoparticles to specific adverse health effects; in essence such 
specific biological markers of exposure or response to engineered nanoparticles suitable for surveillance have not been identified. Clearly, more research is needed to identify these specific health effects. Meanwhile, if hazard surveillance is to be conducted, employers and practitioners may face such challenges as determining which workers may be exposed and which may not, as well as what communications should go to workers with and without exposure.

\section{Should exposure registers be established for various groups of workers potentially exposed to engineered nanoparticles?}

Exposure registers involve the enrollment of workers to indicate information about their exposure so that research can eventually be conducted and timely and targeted risk communication, intervention, or needed advice can be provided (54). Examples of exposure registers that have been established include those for workers exposed to beryllium, ionizing radiation, 2naphthylamine, World Trade Center dust, and residents exposed to trichloroethylene, benzene, and dioxin. Recently, a European Union exposure register on wood dust has been established (55). The issues of importance that should be considered in assessing the utility of exposure registers for nanotechnology workers include (i) register governance, (ii) logistics, (iii) costs, and (iv) psychosocial and legal issues. Exposure registers may serve as the basis for conducting prospective studies of workers exposed to engineered nanoparticles. Such studies could focus on frank adverse health effects, as well as on early indicators or biological markers representative of exposure or disease. However, carrying out epidemiologic studies of nanotechnology workers will be difficult because of the diversity of the workplaces and types of engineered nanoparticles. Exposure registers may also facilitate risk communication and risk management as new risk information becomes available. If exposure registers are to be established, it will probably require government agencies, consortiums of trade associations, or large companies to be involved in the management and logistics. Ultimately, exposure registers may reassure workers that, in the absence of certainty about the extent of risks, attention is being paid to identify possible hazards early. Cooperation by employers in exposure registers may also demonstrate that managements are being proactive regarding worker safety and health.

\section{Should engineered nanoparticles be treated as "new" substances and evaluated for safety and hazards?}

The general pattern of evidence shows that engineered nanoparticles can be more toxic than their bulk counterparts $(7,13,41,56-58)$. Consequently, when introduced into commerce, should produced engineered nanoparticles be treated as new substances? The example of single-walled carbon nanotubes (SWCNT) illustrates the issue. Under current regulations, the permissible exposure limit (PEL) of the Occupational Safety and Health Administration (OSHA) for graphite $\left(5 \mathrm{mg} / \mathrm{m}^{3}\right)$ is often cited on material safety data sheets as the PEL relevant to SWCNT, and both substances have the same chemical formula (C). However, SWCNT has been shown to be more fibrogenic in mice than crystalline silica (8). Shvedova et al (8) estimated that workers could attain a lung burden equivalent to that causing adverse effects in mice if they were exposed to SWCNT over a period of 20 days at the graphite PEL. Recent data from animal models provide evidence that SWCNT may induce mesothelioma in these models $(34,59)$. While this finding will need to be verified by other studies and related to airborne exposures, there may be a need to reconsider specifically the issue of the occupational exposure limits (OEL) of engineered carboneous fibrous nanoparticles. In addition, it is generally appropriate to ask "What are appropriate recommended exposure limits for engineered nanoparticles?" Since nanoparticles appear to be more toxic than their bulk counterparts on a mass basis, should there be different OEL (which are typically based on mass concentration)? With titanium oxide as a model, risk estimates based on experimental data on animals indicate that different-size particles lead to different risks at the same mass exposure concentration and that, to control risks to the same level (eg, 1 in 1000), it may be necessary to have a different OEL (if mass-based) for different size particles, large and small $(41,58)$. Moreover, since a mass-based metric may not be the best indicator of risk, other metrics, such as particle number or surface area, may ultimately be needed in OEL.

When data are not available for quantitative risk assessment, it may be possible to develop an algorithm to adjust the OEL for a bulk material to calculate an OEL for nanoparticles that takes into account the influence of particle characteristics, including size, surface area, and any differences in surface properties (eg, reactivity), between the nanoparticle and bulk material, while also considering the appropriate uncertainty issues (40). The effectiveness of such an approach would depend on the health data basis of the OEL for the bulk material, and the availability of a sufficient database of representative nanoparticles. The development of reference or benchmark materials, including both nanometer- and micrometer-scale particles of the same material and which are well-characterized in terms of physiochemical characteristics and biological activity and toxicity, is a useful step towards understanding and classifying the relative hazard or safety of specific nanoparticles. These issues 
raise the question of whether, before "nanoparticles" are entered into the market, should they be subject to the regulatory requirements for any new substance. This question is being debated in the European Union. Currently, nanoscale-size substances fall under the scope of the REACH (registration, evaluation, authorization, and restriction of chemical substances) regulation, but because nanomaterials may be manufactured or imported below the threshold of one ton per year, they may evade REACH registration requirements (60).

\section{Concluding remarks}

The effective safety assessment of engineered nanoparticles probably requires the development of a classification algorithm to identify potential hazards of different types of engineered nanoparticles. The great challenge for the classification is which of the metrics or characteristics (ie, particle size, surface area or reactivity, chemical composition, or some other characteristics of the engineered nanoparticles) should be used to classify engineered nanoparticles. In evaluating exposure to engineered nanoparticles in occupational environments, two challenges remain as top priority. New easy-to-use portable devices capable of capturing information on particle number and surface area and other characteristics need to be developed because such devices are the prerequisite for exposure database generation. Another key challenge is to differentiate between the levels of engineered nanoparticles and ubiquitous background levels of incidental, mainly combustion-derived nanoparticles. There are many different workplaces in which exposure to engineered nanoparticles can take place. Therefore, different monitoring strategies and different monitoring devices may need to be developed if the knowledge base is to become more comprehensive. Meanwhile, being cautionary and minimizing exposure may be the best way to deal with the potential hazards potentially evoked by exposure to engineered nanoparticles. To prevent the exposure of workers to engineered nanoparticles, clean rooms and closed processes are the most effective, but, in cases in which such circumstances are not possible, tailored exhaust ventilation and personal protection equipment with appropriate performance characteristics are available. In addition, as a safeguard to detect potential adverse health effects of workplace exposure, medical surveillance programs may be warranted. However, specific health end points or biomarkers have not been validated. Moreover, health end points from engineered nanoparticle exposures are obscure, and hence the best available approach today is hazard monitoring, and the prudent use of controls.

In the future, an assessment of the safety of workers exposed to engineered nanoparticles may require the establishment of exposure registers. Such registers can be individual worker or company-based exposure registers. Currently, the development of individual worker-based registers would be overwhelmingly challenging due to the lack of personal monitoring devices and because of legal issues. Thus, today, company-based exposure registers may be the most appropriate alternative. There is growing support that engineered nanoparticles should be classified as new substances because of the accumulating evidence that material at the nanoscale can have novel biological properties that differ dramatically from the properties of the same chemical in a bulk form. This evidence also implies that, in addition to classifying engineered nanoparticles as new substances a priori, there will be a need for new approaches, such as using surface area metrics and surrogate toxicity end points for the setting of occupational exposure limits once the necessary information is available.

\section{Acknowledgments}

The findings and conclusions in this report are those of the authors and do not necessarily represent the views of the National Institute for Occupational Safety and Health.

The authors thank the following persons for their comments on earlier drafts of the paper: Kenneth Mundt, Diane Mundt, Randy Ogle, and Lang Tran.

\section{References}

1. Feynman R. There's plenty of room at the bottom [Internet]. Pasadena (CA): California Institute of Technology (Caltech) [cited 6 August 2008]. Available at http://www.zyvex.com/ nanotech/feynman.html.

2. Takenaka S, Karg D, Roth C, Schulz H, Ziesenis A, Heinzmann $\mathrm{U}$, et al. Pulmonary and systemic distribution of inhaled ultrafine silver particles in rats. Environ Health Perspect. 2001;109(suppl. 4):547-51.

3. Oberdörster G, Sharp Z, Atudorei V, Elder A, Gelein R, Lunts A, et al. Extrapulmonary translocation of ultrafine carbon particles following whole-body inhalation exposure of rats. J Toxicol Environ Health Part A. 2002;65:1531-43.

4. Bermudez E, Mangum JB, Wong BA, Asgharian B, Hext PM, Warheit DB, et al. Pulmonary responses of mice, rats, and hamsters to subchronic inhalation of ultrafine titanium dioxide particles. Toxicol Sci. 2004;77:347-57.

5. Lam CW, James JT, McCluskey R, Arepalli J, Hunter. Pulmonary toxicity of single-wall carbon nanotubes in mice 7 and 90 days after intratracheal instillation. Toxicol Sci. 2004;77:12634.

6. Geiser M, Rothen-Rutishauser B, Kapp N, Schürch S, Kreyling W, Schulz H, et al. Ultrafine particles cross cellular membranes by nonphagocytic mechanisms in lungs and in cultured cells. Environ Health Perspect. 2005;113(11):1555-60.

7. Oberdörster G, Oberdörster E, Oberdörster J. Nanotoxicology: an emerging discipline evolving from studies of ultrafine particles. Environ Health Perspect. 2005;113(7):823-39.

8. Shvedova AA, Kisin ER, Mercer R, Murray AR, Johnson VJ, Potapovich AI, et al. Unusual inflammatory and fibrogenic 
pulmonary responses to single walled carbon nanotubes in mice. Am J Physiol Lung Cell Mol Physiol. 2005;289(5): L698-708.

9. Elder A, Gelein R, Silva V, Feikert T, Opanashuk L, Carter J, et al. Translocation of inhaled ultrafine manganese oxide particles to the central nervous system. Environ Health Perspect. 2006;114:1172-78.

10. Mercer RR, Scabilloni JF, Wang L, Kisin ER, Murray AR, Schwegler-Berry D, et al. Alteration of deposition pattern and pulmonary response as a result of improved dispersion of aspirated single walled carbon nanotubes in a mouse model. Am J Physiol Lung Cell Mol Physiol. 2008;294:187-97. doi: 10.1152/ajplung.00186.2007.

11. Dockery DW, Pope CA, Xu X, Spengler JD, Ware JH, Fay ME, et al. An association between air pollution and mortality in six U.S. cities. N Engl J Med. 1993;24:1753-59.

12. Oberdörster G. Pulmonary effects of ultrafine particles. Int Arch Occup Environ Health. 2001;74:1-8.

13. Donaldson K, Brown D, Clouter A, Duffin R, MacNee W, Renwick $\mathrm{L}$, et al. The pulmonary toxicology of ultrafine particles. J Aerosol Med. 2002;15:213-20.

14. Maynard AD, Kuempel ED. Airborne nanostructured particles and occupational health. J Nanoparticles Res. 2005;7:587614.

15. Gwinn MR, Vallyathan V. Nanoparticles: Health effects pros and cons. Environ Health Perspect. 2006;114:1818-25.

16. European Commission. List of activities in the FP7 calls for proposals of 2008 of direct relevance to nanotechnology [Internet]. Brussels: European Communities; 2007 [cited 13 February 2008]. Available from: ftp://ftp.cordis.europa.eu/pub/ nanotechnology/docs/call-2008_nano.pdf.

17. Kandliker M, Ramachandran G, Maynard A, Murdock B, Toscano WA. Health risk assessment for nanoparticles: a case for using expert judgement. J Nanoparticle Res. 2007;9:137-54.

18. Aitken RJ, Creely KS, Tran CL. Nanoparticles: an occupational hygiene review. Norwich (UK): HSE Books; 2004. 113 p. Health and safety executive research report, no 274.

19. National Institute for Occupational Safety and Health (NIOSH). Approaches to safe nanotechnology: an information exchange with NIOSH [Internet]. Cincinnati $(\mathrm{OH})$ : NIOSH; 2006. 43 p [cited 11 February 2008]. Available from: http:// www.cdc.gov/niosh/topics/nanotech/safenano/.

20. Health and Safety Executive (HSE). Nanotechnology HSE information note: horizons scanning information. London: HSE; 2004; 4 p. Note No HSIN1.

21. European Commission. Nanosciences and nanotechnologies: an action plan for Europe 2005-2009 [Internet]. Brussels: European Communities; 2005 [cited 5 August 2008]. Available from: ftp://ftp.cordis.europa.eu/pub/nanotechnology/docs/ nano_com_en.pdf.

22. Boccuni F, Rondinone B, Petyx C, Lavicoli S. Potential occupational exposure to manufactured nanoparticles in Italy. J Clean Product. 2008;16(8-9):949-56.

23. Morawska L, Moore MR, Ristovski ZD. Health impacts of ultrafine particles. Canberra (Australia): Australian Department of the Environment and Heritage; 2004.

24. Nikula KJ, Snipes MB, Barr EB, Griffith WC, Henderson RF, Mauderly JL. Comparative pulmonary toxicities and carcinogenicities of chronically inhaled diesel exhaust and carbon black in F344 rats. Fundam Appl Toxicol. 1995;25:80-94.

25. Heinrich U, Fuhst R, Rittinghausen S, Creutzenberg O, Bellmann B, Koch W, et al. Chronic inhalation exposure of Wistar rats and two different strains of mice to diesel engine exhaust, carbon black, and titanium dioxide. Inhal Toxicol.
1995;7:533-56.

26. Li Z, Hulderman T, Salmen R, Chapman R, Leonard SS, Young SH, et al. Cardiovascular effects of pulmonary exposure to single-wall carbon nanotubes. Environ Health Perspect. 2007;115:377-82.

27. Porter AE, Gass M, Muller K, Skepper JN, Midgley P, Welland M. Direct imaging of single-walled carbon nanotubes in cells. Nat Nanotechnol. 2007;2:713-17.

28. Porter AE, Gass M, Muller K, Skepper JN, Midgley P, Welland $\mathrm{M}$. Visualizing the uptake of $\mathrm{C} 60$ to the cytoplasm and nucleus of human monocyte-derived macrophage cells using energyfiltered transmission electron microscopy and electron tomography. Environ Sci Technol. 2007;41(8):3012-17.

29. Oberdörster G, Sharp Z, Atudorei V, Elder A, Gelein R, Kreyling W, et al. Translocation of inhaled ultrafine particles to the brain. Inhal Toxicol. 2004;16(6-7):437-45.

30. Ryman-Rasmussen JP, Riviere JE, Monteiro-Riviere NA. Penetration of intact skin by quantum dots with diverse physiochemical properties. Toxicol Sci. 2006;91(1):159-65.

31. Institut de Recherche Robert-Sauvé en Santé du Travail (IRSST). Nanoparticles: actual knowledge about occupational health and safety risks and prevention measures [Internet]. Montreal (Canada): IRSST; 2006 [cited 11 February, 2008]. Studies and research projects R-470. Available from: http:// www.irsst.qc.ca/files/documents/PubIRSST/R-470.pdf.

32. British Standards Institute (BSI). Nanotechnologies part 2: guide to safe handling and disposal of manufactured nanomaterials. Bristol (United Kingdom): BSI; 2007. PD6699-2:2001.

33. Pylkkänen L, Alenius H, Tuomi T, Savolainen K. The effect of nanoparticles on the expression of mRNA and proteins of chemokines and cytokines in inflammatory cells in the lungs. The Sixth Princess Chulabhorn International Science Congress; 25-29 November 2007, Bangkok, (Thailand). Bangkok: Amarin Printing and Publishing Public Company Ltd; 2007. p 237-41.

34. Poland CA, Duffin R, Kinloch I, Maynard A, Wallace WH, Seaton A, et al. Carbon nanotubes introduced into the abdominal cavity of mice show asbestos-like pathogenicity in a pilot study. Nat Nanotechnol. 2008;3:423-28. doi: 10.1038/ nnano.2008.111.

35. Nel A, Xia T, Madler L, Li N. Toxic potential of materials at the nanolevel. Science. 2006;311(5761):622-27.

36. Limbach LK, Widmer M, Husmann F, Gehr P, Blank F, Riediker M, et al. Exposure of engineered nanoparticles to human lung epithelial cells: influence of chemical composition and catalytic activity on oxidative stress. Environ Sci Technol. 2007;41:4158-63.

37. Oberdörster G, Ferin J, Lehnert BE. Correlation between particle-size, in-vivo particle persistence, and lung injury. Environ Health Perspect. 1994;102(S5):173-9.

38. Driscoll KE. Role of inflammation in the development of rat lung tumors in response to chronic particle exposure. In: Mauderly JL, McCunney RJ, editors. Particle overload in the rat lung and lung cancer: implications for human risk assessment. Philadelphia (PA): Taylor \& Francis; 1996. p 139-52.

39. Duffin R, Tran L, Brown D, Stone V, Donaldson K. Proinflammogenic effects of low-toxicity and metal nanoparticles in vivo and in vitro: highlighting the role of particle surface area and surface reactivity. Inhal Toxicol. 2007;19(10):849-56.

40. Kuempel ED, Geraci CL, Schulte PA. Risk assessment and research needs for nanomaterials: an examination of data and information from current studies. In: Kuempel E, Geraci C, Schulte P, editors. NATO advanced research workshop on 
nanotechnology: toxicological issues and environmental security. Netherlands: Spinger Netherlands; 2007. p 119-45.

41. Dankovic D, Kuempel E, Wheeler M. An approach to risk assessment for $\mathrm{TiO}_{2}$. Inhal Toxicol. 2007;19 suppl 1:205-12.

42. Renwick LC, Brown D, Clouter A, Donaldson K. Increased inflammation and altered macrophage chemotactic responses caused by two ultrafine particle types. Occup Environ Med. 2004;61(5):442-7.

43. International Organization for Standardization (ISO). Workplace atmospheres-ultrafine, nanoparticle, and nano-structured aerosols-inhalation, exposure characterization and assessment. Geneva: ISO; 2007. p 34. ISO/TR 27628:2007.

44. Maynard AD, Aitken RJ. Assessing exposure to airborne nanomaterials: current abilities and future requirements. Nanotoxicology. 2007;1:26-41.

45. Mazzuckelli LF, Methner MM, Birch ME, Evans DE, Ku BK, Crouch K, et al. Identification and characterization of potential sources of worker exposure to carbon nanofibers during polymer composite laboratory operations. J Occup Environ Hyg. 2007;4(12):D125-30.

46. Maynard AD, Baron PA, Foley M, Shvedova AA, Kisin ER, Castranova V. Exposure to carbon nanotube material: aerosol release during the handling of unrefined single walled carbon nanotube material. J Toxicol Environ Health. 2004;67(1):87107.

47. Schulte PA, Geraci CL, Zumwalde R, Hoover M, Kuempel E. Occupational risk management of engineered nanoparticles. $\mathrm{J}$ Occup Environ Hyg. 2008;5:239-49.

48. Organization for Economic Co-operation and Development (OECD). Report of the OECD workshop on the safety of manufactured nanomaterials: building co-operation, co-ordination and communication, Washington DC, United States, 7th-9th December 2005. Paris: OECD; 2006. OECD environment health and safety publications series on the safety of manufactured nanomaterials, no 1.

49. Hinds WC. Aerosol technology: properties, behavior, and measurement of airborne particles. 2nd ed. New York (NY): Wiley Intersciences; 1999.

50. Halperin WE. The role of surveillance in the hierarchy of prevention. Am J Ind Med. 1996;29:321-3.
51. Harber P, Conlon C, McCunney RJ. Occupational medical surveillance. In: McCunney RJ, editor. A practical approach to occupational and environmental medicine. Philadelphia (PA): Lippincott, Williams, and Wilkins; 2003. p 582-99.

52. Wegman DH. Hazard surveillance. In: Halperin W, Baker EL, Monson RR, editors. Public health surveillance. New York (NY): VanNostrand Reinhold; 1992. p 42-75.

53. Schulte PA, Trout D, Zumwalde RD, Kuempel E, Geraci CL, Castranova V, et al. Options for occupational health surveillance of workers potentially exposed to engineered nanoparticles: state of the science. J Occup Environ Med. 2008;50(5):517-26.

54. Schulte PA, Kaye WE. Exposure registries. Arch Environ Health. 1988;43:155-61.

55. Kauppinen T, Vincent R, Liukkonen T, Grzebyk M, Kauppinen A, Welling I, et al. Occupational exposure to inhalable wood dust in the member states of the European Union. Ann Occup Hyg. 2006;50:549-61.

56. Zhang Q, Kusaka Y, Donaldson K. Comparative pulmonary responses caused by exposure to standard cobalt and ultrafine cobalt. J Occup Health. 2000;42:179-84.

57. Zhang Q, Kusaka Y, Zhu X, Sato K, Mo Y, Kluz T, et al. Comparative toxicity of standard nickel and ultrafine nickel in lung after intratracheal instillation. J Occup Health. 2003;45:2330.

58. Kuempel ED, Tran CL, Castranova V, Bailer AJ. Lung dosimetry and risk assessment of nanoparticles: evaluating and extending current models in rats and humans. Inhal Toxicol. 2006; 18:717-24.

59. Takagi A, Hirose A, Nishimura T, Fukumori N, Ogata A, Ohashi N, et al. Induction of mesothelioma in p53+/- mouse by intraperitoneal application of multi-wall carbon nanotube. J Toxicol Sci. 2008;33(1):105-11.

60. Commission of the European Communities. Communication from the Commission to the European Parliament, the Council and the European Economic and Social Committee: regulatory aspects of nanomaterials. Brussels: Commission of the European Communities; 2008.

Received for publication: 9 August 2008 